\title{
TABLIGHI MOVEMENT OF 20TH CENTURY: SIX PRINCIPLES
}

\author{
Rameez Ahmad Lone \\ Senior Research Fellow and Assistant Prof. (Contr.) Department of Sociology GDC Sopore, J \& K
}

Article DOI: https://doi.org/10.36713/epra8426

DOI No: 10.36713/epra8426

\begin{abstract}
Tablighi Jamaat is one of the most prominent and most widespread Islamic missionary movements of $20^{\text {th }}$ century Islam. It's active today almost in every country wherever Muslims live. The organization is said to be having a presence in between 150 to 200 countries, with its estimated adherents numbering between twelve million to one hundred fifty million, the majority of which are living in South Asia. It primarily focuses on making Muslims better and purer Muslims. When they visit a village or any place, they invite local people to assemble in a mosque and present their message in the form of six principles. These six principles are commonly called "chai baati" (six talks) in Tablighi circles. These six principles are: Kalimah 'Article of Faith', Salah 'Prayers', Ilm and Zikr 'Knowledge and Remembrance of God', Ikraam-i-Muslim 'Respect for Muslim', Ikhlase-Niyyat, 'Sincerity of Intention' and Tafrigh-i-waqt 'Sparing of time in tabligh (preaching)'. These six principles are fundamental to the teachings of 'Tablighi Jamaat' and represent the basic ideological structure of the Tablighi Movement.

KEY WORDS: Tablighi Jamaat, Six Principles, Preaching, Muslims.
\end{abstract}

Tablighi Jamaat which literally means 'preaching group or party' was founded by Maulana Mohamad Ilyas Kandhalvi in 1920's in Mewat-India. In its course of dawah 'preaching' work, Maulana Ilyas required Tablighi activists to strictly follow 'six principles' or which in Tablighi circles are commonly referred as chai baatien 'six talks'. These six principles represent a sort of 'ideological structure' of the Jamaat, which according to 'Tablighi Jamaat' is fundamental for the renewal of faith among the Muslims at the basic level, which will help in their knowledge, cultivation of faith, moral and spiritual development (Lone, 2018; Sikand, 1986; Mumtaz, 1991). However some scholars like, Agwani, (1986: 43-45), Anawrul Haq (1973:142) and Lone (2018), that Ilyas required seven essentials for the Tablighi activists to concentrate on, while in a dawah or preaching tour. These six principles 'chai baatie' viz. i. Shahadah, ii. Namaaz, iii. Ilm-o zikr, iv. Ikrami-Muslim, v. Ikhlas-i-niyat and vi. Tafrigh waqt are the fundamental one's and the 'seventh' one that is, tarq-ilayani 'giving meaning less persuits' is of general character. In all, these could be referred as 'seven essentials' containing six fundamentals (ibid, 2018). However, Anwarul, Haq (Haq, 1972:142-45), has referred these principles or essentials as 'six positive' and one negative, while as Maulana Wahidudin Khan (Khan, 1986: 24) maintained, that, Maulana Ilyas's plan was comprised of 'six important aims'. Mumtaz Ahamad (Ahmad, 1991), is of the view, that Maulana Ilyas's plan comprised of small, mobile units of Tablighi Jamaat activists, containing around and at least 10 to 12 members, who were required to travel to various villages for preaching and to present their dawah 'preaching' messages according to the six demands.

These principles, which lie at the base of Tablighi dawah 'preaching' ideology and methodology, have been discussed systematically in the following pages.
(A) PROFESSION OF FAITH/TESTIMONY (KALIMA SHAHADAH)
The first one is the 'Kalima' (also called article of faith), which is as follows : 'La Illha Illa'Llahu, Muhamamadu-r-Rasool-ull Llah' meaning 'that there is no deity but God- Almighty Allah, and Muhammad is the Apostle and servant of Allah'. Ilyas's message gives prime importance to the Kalima; to believe in the reality that there is no deity but God Almighty Allah, that $\mathrm{He}$ alone is the Creator and the Nourisher of the universe, and the 
truth had been made manifest through His messenger, the Prophet Muhammad(PBUH). When one recites these words: that there is no deity but God Allah and the Prophet Muhammad is His last messenger and servant, it amounts to expressing one's inner feelings of conviction of the truth, of these words. It also proclaims ones determination to follow a path based on the firm conviction that God Allah is the only real existence, the centre of all our complete trust. This proclamation is an expression of an all-pervasive feeling within one of having at last found the true way of life and also the source from which truth emanates- the only source whose guidance is worthy of trust.

Trust and conviction are, in fact, the source of all revolution, be it religious or secular. A history of revolution tells us that it was the courage of conviction-right or wrong-in certain souls, which has made history. For instance Maulana Wahidudin Khan (W. Khan, 1986: 25), gives the example of communism, though was based on partial truth, yet some political, economic or nationalistic truths or convictions, aroused and inspired people to such a degree that they concentrated all their potentialities and energies on making it known to people. One can then imagine what the strength of such a conviction would be like when based on a truth in real sense of the word. When such truths are firmly implanted in ones heart and mind, like a divine fervour, one can guess what enormous benefits can result. The true faith, over which the people have put their total trust in God Allah, has the potential to move all mankind. The kalimah is thus the essence of religion- the greatest power on the earth. The movement can be thus appropriately called a 'Kalimah movement or 'Tahreek Emaan'( ibid., 26).

The Kalima has to be memorized correctly, paying particular attention to pronunciation at least uttered correctly. The emphasis is on understanding its significance as a divine command. The article has broadly two aspects: one having the belief, that God Almighty Allah is alone deity worthy of worship; and second having a belief that the last Messenger of Allah's way that is, the Prophet's Mohammad's way is the right way and final way to worship or establish connection with God-Allah. In other words 'Kalima' has two parts that is, belief and testimony in one Allah and; testimony and obedience to the Prophet Muhammad (PBUH). Besides the 'Kalima' is sometimes also referred to as 'faith' or 'emaan'. The word 'emaan' in Arabic describing faith literally means 'believing in the words of the messenger with full conviction and certainty. The word of faith 'Kalima' thus means expressing belief in the message of Allah, conveyed through His Messenger with full conviction, confidence and certainty (Haq, 1972; Kandhalavi, 2009)

\section{(B) PRAYERS (SALAH OR NAMAAZ)}

The second important part of the Maulana Ilyas's call is to prayer or Namaaz or Salah. Here Tablighi Jamaat activists learn about the various details and rules of Namaaz, the obligatory and other prayers, as well as rules about the ritual purity. Just as 'Kalima' enjoys the main position in one's thoughts and feelings, so does prayer in ones practical life. The real significance of prayer lies in men diverting all his attention to God Allah and making contact with Him through sense perceptions. Through them the worshipper bows before his Lord, placing his forehead on the ground, he testifies to his own lowliness as opposed to God-Allah's exalted nature. He presents himself as Allah's servant. He stands before Allah, bows down to Him, and prostrates himself before Him, in a practical demonstration of submission to Allah. It is when one humbles oneself before the Lord that one is in a position to meet Him; for one discovers Allah on a level of humility, not on a level of pride or egotism. One's soul then undergoes such an experience that one can feel the blessing of God-Allah descending upon one. Such an experience, which defies description, gives a new dimension to human personality. The worshiper consciously realizes how helpless and powerless he is before God Almighty Allah. Humility and modesty alone befit a servant of God-Allah. In the process, arrogance and haughtiness, which are the source of most evils, vanish into thin air.

Prayer, as mentioned in the Quran, keeps one away from evils and shameful practices and is the only manifest difference between a Muslim and a kafir ${ }^{1}$. With every prayer, man expresses his servitude before God and promises to Him that he will try to lead his life as His devoted servant. It reminds him of the day of reckoning. If a man is true to his words, his life can be transformed by them.

Besides, in the first principle, the pledge of worship and obedience to Allah and His Prophet

\footnotetext{
${ }^{1}$. Kafir denotes 'atheist' or one who does not believe in one God or Allah and His Messenger Muhammad.
} 
are fulfilled through prayers and prayers are the first practical step towards proof of one's faith. Prayer also has two parts, external and internal. The former consists in performing the preludes to prayer such as ablutions, involving all the acts which the Prophet and his Companions performed. These are to be done exactly the same way as Prophet did them. In the internal sense, prayer is to strive for perfect submissiveness in every single act which will create in the individual the quality of abstention from vile deeds. This is the real meaning of prayers (Haq, 1972; W. Khan, 1986 ; Kandhalavi, 2009).

\section{(C) KNOWLEDGE AND REMEMBERANCE OF GOD-ALMIGHTY ALLAH (ILM-O- DHIKR OR ZIKR)}

The third essential principle is the acquiring knowledge and remembering God Allah all the time. In Tablighi parlance, this principle is referred as 'Ilm-o-Zikr'. Every day a part of the morning and evening hours is to be spent for this purpose. There are general and special forms of remembrance. As regards the former, a Muslim is expected to recite the tasbiha ${ }^{2}$ (one hundered times) of the third kalimah and two tasbih each of the durood $^{3}$ and istighafaar ${ }^{4}$. A specific time is to be fixed for these devotions. In addition, special devotions are to be offered by those who are to be disciples of the shaykh in accordance with the manner prescribed by him.

To acquire the religious knowledge certain books are to be studied, such as Faza'il namaz, Faza'il Quran, Faz'il zikr, Faza'il ramazan, Faza'il hajj, Faza'ilsadakaat, and Hikayat-i-sahaba. These books are in Urdu and are meant for Muslims in general. For the 'ulama' various sections from Sahih-al Bukhari are prescribed: 'kitab al-iman (book of faith), kitab al-ilm(book of knowledge), al-itisam bil-kitab wa al-sunnah (adherence to Quran and the Practice of the Prophet), kitab aljihad (book of struggle), al-amr bill-maruf wa alnahi 'an-al munkar, kitab al-adab, kitab al-riqaq and kitab al-fitan (Haq, 1972).

\footnotetext{
2 . Praises of God-Allah; counting of beads one hundred times; rosary.

3 . Darood, simply means paying salutation to Prophet Muhammad.

4 'Istighafaar' is the act of seeking forgiveness from Allah, by reciting Arabic word 'Astaghfirullah', repeatedly meaning "I seek forgiveness from Allah". Various other dua's are also recited for this purpose. It is considered one of the essential parts of worship in Islam.
}

The details of this divine command, its correct procedures are needed to be learnt through the learned scholars of religion. Usually, three procedures are to be adopted to get this particular aspiration of 'acquiring knowledge'. These are:

(a) By making urge for knowledge to other faithful Muslim brothers especially the Ulama.

(b) By making self efforts to acquire it, and;

(c) By prostrating before God or seeking Allah's help for the achievement of this goal.

Besides the Quran and Sunnah (hadith), relevant books as described above are believed to be a great source of knowledge. The contents are to be acquired and installed in the heart to mean that the knowledge is really acquired. Mere reading, understanding or its memorizing does not carry any merit. The knowledge in true sense is one that is conveyed by the creator of the universe through His messenger for the guidance of the mankind, which is revealed in the divine books of Quran and Hadith. The knowledge has got importance and so is honoured. The ignorance has got no value and can bear no fruit. Knowledge alone is going to be useful in the grave and ignorance can never. Only those who acquired knowledge and acted upon will be able to pass through various trials and tests in the grave or on the Day of Judgment and thus will be able to shield or free themselves from the hellfire. Ignorance, or even knowledge with weak belief, or without compliance too will prove useless. The lives of the Prophet and his companions are the model for the Muslims about acquiring knowledge and acting upon (ibid).

\section{(D) RESPECTING MULIMS (IKRAAM-E- MUSLIM)}

To pay due respect to the Muslims, called 'Ikram-e-Muslim' in Tablighi terminology, forms next important principle of the Tablighi Jamaat's preaching project. Maulana Ilyas emphasized that honor and deference should be shown to fellow Muslims, especially in the matter of rights. In addition to this, it is the special right of the young to be treated with affection by the elders, while elders are to be shown deference by the younger generation. At the same time Maulana Ilyas, emphasized that rights are only a means to an end, the end being the spread of Islam. In the pursuit of this goal, one should be prepared to sacrifice one's own rights, for which one will be rewarded in the hereafter.

Thus, 'Ikram-i-Muslim' also stands for respecting others rights and not insisting ours. We should invariably fulfil the obligations towards 
other human beings as commanded by Allah, and as taught by Prophet Muhammad. We should do this task as a duty and should never demand our own right upon them. It should be our effort to serve others, in whatever way it is possible. Besides, it should be always our concern not to become a cause of trouble or problem for others. The poor needy, neighbour, should be taken care of. The elders, scholars, pious, should be looked with due regards. The weak, young and poor should be treated with compassion. We should overlook the weakness of others if we happen to come across. Allah will overlook our weakness on the Day of Judgment. We should understand the worth of our faithful Muslim brothers. It is reported in a Hadith, that Allah will continue to sustain the universe till that day all the faithful are dead. So Muslims are very dear to Almighty Allah. We find all the infighting, quarrels a today are because people generally enforce their rights on others and forget their duties towards them. It is the main cause of the quarrels and broken family bonds all around in the society now-days. We should volunteer ourselves for serving our brethren, the needy. The Prophet Muhammad and his companions have a set of excellent sacrifice of self interest for us to replicate. It is narrated that once the Prophet had set on a tour along with the companions. On the way they made a halt for a while for lunch. While others were busy in cooking, Prophet volunteered himself to collect the firewood. He has thus show-cased an excellent example of fraternity, service and social work. He always behaved one among the many. While in Jamaat or 'Tablighi tour' one should put aside his individual identity, status and act as one among the participants and act for the welfare of others (ibid).

The other aspect of this fourth principle is akhlaque meaning 'character building and imbibing moral values' and haquq-ul-ibaad meaning 'rights of the human beings' encompassing rights of the Muslims as well as mankind. It is through these moral values, character building and showing sympathy to Muslims and non Muslims like poor, sick, elderly and other needy Islamic teachings could be practically disseminated (Zainuddin 2020).

\section{(E) PURITY AND SINCERITY OF INTENTION (IKHLAS-E-NIYAT)}

The fifth, important principle also called 'Ikhlas-eniyyat'- in Tablighi parlance is concerned with emendation of intention and sincerity. Every action is to be undertaken with no other end in view but to please God Almighty Allah, and to reform oneself. Any slightest deviation from this set path is bound to generate the wrath, anger of Allah instead as it tantamount to admitting partner in that deed. According to one hadith (sayings of the Prophet Mohammad), a religious scholar, a philanthropist and a crusader will be brought before Almighty Allah on the Day of Judgment. They will be asked one by one to explain their behavior in the life. They will happily report about their performances and achievements. Allah will declare that their acts were with the intention to gain publicity and fame. It was achieved and nothing remains for them as a reward. They will be then ordered to be thrown in the fire of hell. It is also said that one of the attributes of Allah is being 'Pure' and He accepts only such deeds which are offered purely with an intention to gain His pleasure only. Hence the Muslims or the Tablighi activists must ensure 'perfect purity in intention' is achieved at all costs. An impure act is dangerous and a way definite towards hell. A small act with purity in intention is great, considered acceptable and fully reward-able by Allah compared to a big one but with a slightest corruption in intention (ibid).

Thus Tablighi's must perform every act with the sole purpose to please Allah and not for any selfish purpose like earning fame or name. If they do so then their acts would not only disqualify them for any reward but will also invite them punishment of Allah

\section{(F) SPARING TIME IN THE PATH OF ALLAH OR MISSIONARY TOURS.}

Also called 'Tafrigh-i- waqt' in Tablighi terminology, means to spare time, that is, to withdraw from ones worldly engagements and to go forth in missionary groups. This sixth principle 'making people come out of their homes' is central to the Maulana Ilyas's way of working, because this gives people the opportunity to quit their worldly atmosphere and to go in search of religious one. Only in atmosphere free of worldly thoughts can be there a true receptivity to the message concerned. Ilyas is reported to have once said, 'our method of working, lays emphasis upon taking people out of their homes in groups. The main advantage of this method is to encourage people to come out of worldly and static atmosphere in order to enter a new, pure and dynamic one where there is much to foster the growth of the religious consciousness. Besides, travel and emigration involve hardship, sacrifice and self-abnegation for 
the sake of God-Allah's cause, and thus entitle one to divine succor (Khan, 1986:29).

This principle has also been referred as 'the course of action' in the Tablighi literature, because this is the principle where Muslims or Tablighi activists are practically taught the above five principles. Thus this principle may be described as the essence or soul of Tablighi project. While at his own place, one should move to bring people together for Salah (congregational prayers/prayers), Zikr remembrance of Allah etc., in the local mosque. The fellow Muslim brothers should be argued to assemble in the evening and to stay back in the mosque to offer late night Salah (prayer) called 'tahajud'. Supplication for forgiveness', guidance for all should be made to Almighty with a humble and begging posture. Again by persuasion a Jamaat should be formed to move out for three days to a nearby place. Some seniors should brief the junior participants the correct procedure of spending the time while in the path of Allah. A senior, learned among the group will be selected to head them to be called 'Ameer' of the group. The other important persons are the 'Mutakalim' that is, a talk-giver and, a 'Rahbar' that is, a guide- a local person of a village or an area where the Tablighi Jamaat visits. A 24 hour program is prepared everyday in the morning to practice to bringing of the 'six principles' in the lives of the participants. For this, the prescribed books are also read and recited while in the Jamaat. The Muslims living in the village or around the mosque are contacted and invited, with an urge to join the Jamaat and follow the same procedures for the success. This is done through the 'ghast' that is, Tablighi activists patrol in the locality around the mosque and went door to door or house to house while inviting people to mosque. The patrolling usually lasts for an hour, and the tablighi activists must return before 5 to 10 minutes before the salath (prayer). After Salaat, the 'Mutakalim' delivers speech or talk in a simple manner in the light of six principles to enlighten about the need of strengthening bond of Muslims with the GodAllah. After this, a call is given by the 'Ameer' usually in a gathering called 'tashkeel' to the local

5. tashkeel, literally means 'put in pictures, practice, action or words' In tablighi parlance, it refers to a special call on the part of head or ameer of the tabligi jamaat to the local people about joining the tablighi tour for specific periods of time, usually 3, 7,10,40 (0ne chillah), and 120 days. Those accept the call, either raise their hands, or stand up, to register their names as per their convenience. The names are written by one people, to join the Jamaat. Upon joining by some local people, similar groups numbering from 3-11 are formed there and dispatched to other places to work on the same pattern, for a convenient period that is, 3 days, 10 days, 40 days, 4 months etc. The dos and don'ts supposed to be observed while in the path are learnt from the seniors (Kandhalavi, 2009).

Thus, 'sixth principle' of the movement deals with the formation of the groups, of the volunteers, willing to donate their time for preaching tours. It advocates that it is the duty of every member of the community to call others to religion, just as in the past it had been the preoccupation of those who had accepted Islam upon the hand of the Prophet (Haq, 1972: 145)

These six positive (Haq, 1972) and fundamental principles are to be observed constantly by the members of the touring group. The seventh essential principle or rule is of prohibitive nature. This principle in Tablighi parlance is called "Tarq-i-La'ya'ni" meaning, 'giving up useless actions or deeds'. This principle calls upon the Muslims or Tablighi activists to abstain from wasting time in unnecessary talks, futile actions, sinful and prohibitive deeds. Besides these six principles (including the seventh) can be condensed into three main tenets:

'The 'Kalimah Tauhid', Article of Faith 'Salah' prayers and 'Tafrigh-i- waqt' sparing time for preaching. The other three are, in actual fact, offshoots of the main tenets. When they are adopted wholeheartedly all other things follow in consequence (Khan, 1986). And, when one 'spares time', in Tabligi tours, he in the due course of time, learns by default about the other principles of the Jamaat. Besides and because, one must note that these 'Tablighi' mobile units are not just formed to preach among people, but fundamentally to learn about Islam in the light of above mentioned six principles. So in the Tablighi Jamaat, the members both learn and practice these six principles.

\section{CONCLUSION}

The above mentioned six principles form the backbone of Tablighi Jamaat's dawah project encompassing its ideology and methodology. The first principle that is, Kalima profession of faith is the fundamental of all, all other principles follow logically and consistently. If one believes whole heartedly in

of the tabligji member on the dairy. The registered people are contacted and departed for tablighi tours, for various places.s 
Allah the way taught by Prophet Mohammad (PBUH), it is natural he will pray regularly, remember and praise Allah always, show respect to Muslims and mankind, spare time for learning and preaching Islam for the sake of Allah alone. However, the other distinguishing characteristic of Tablighi Jamaat's ideology and methodology is its fifth principle, Tafrigh- $i$ - waqt that is, sparing time in touring and patrolling from one place to another place or from one mosque to another mosque while learning and practicing the Islam which also includes learning of rest of the principles and their injunctions. It is primarily this principle of preaching methodology 'Tafrigh-i- waqt (touring, travelling and patrolling), which distinguishes Tablighi Jamaat from other Islamic revival movements. Moreover, each and every Tablighi activist is strictly advised to abide by these principles both in the Jamaat as well as in his personal life. In nut shell, Tablighi Jamaat's core ideology is confined to these six principles (basic rituals) and unlike Jamaati Islami does not have any explicit and elaborate social, political and economic agenda.

\section{REFERENCES}

1. Agwani, M. . (1986). Islamic Fundamentalism in India. Chandigarh: Twenty-First Century India Society.

2. Ahmad, M. (1991). Islamic Fundamentalismin South Asia: The Jam'at-i-Islami and the Tabligi Jamaat of South

3. Asia. In M. E. Marty, R. S. Appleby, \& S. Asia (Eds.), Fundamentalisms Observed. Chicago and London:

Univrrsity of Chicago.

4. Alam, S. A. Z. M. (1985). The Message of Tableeg and Da'wa. Dhaka: Islamic Foundation Bangladesh.

5. Baliyavi, M. U. (n.d.). Tarikh-i-Da'wat-o-Tabligh. Dehli: Arshi Publications.

6. Baliyavi, M. U. (2013). Tarikh-i-Dawa'at-oTabligh. Dehli: Arshi Publications.

7. Bulandsahri, M. A. E. (1989). Six Fundamentals of Tabligh. New Dehli: Idara-i-Isha'at-i-Diniyat.

8. Falahi, U. F. (1996). Tarikh-i-Da'wat-o-Jihad Baresaghir ke Tanazur main. Dehli: Hindustan Publications.

9. Ferozepuri, M. I. (n.d.-a). Tabligh ka Muqami Kaam (2011th ed.). Dehli: Rabbani Book Depot.

10. Ferozepuri, M. I. (n.d.-b). Tablighi jama'at ki Layi Ranvangi ke Hidayat. Dehli: Rabbani Book Depot.

11. Ferozepuri, M. I. (n.d.-c). Tablighi Tehreekh ki Ibtida aur uski Bunyadi Usool. Dehli: Rabbani Book Depot.

12. Haq, S. A. (1972). The Faith Movement of Maulana Mohammad Ilyas. London: George Allen and Unwin.

13. Kandhalavi, M. S. (2009). The Six Numbers.
Hyderabad: Nasir Book Depot.

14. Khan, W. (1986). Tabligh Movement. New Dehli: the Islamic Centre.

15. Lone, R. A. (2018). Tablighi Jamaat: Ideological Structure, 8(1), 1001-1011

16. Masud, K. (2000). Travellers in Faith: Studies of the Tablighi Jama'at as a Transnational Islamic Movement for Faith Renewal. Brill: Leiden.

17. Sikand, Y. (2002). The Origins and Development of the Tablighi Jama'at (1920-2000). New Dehli: Orient Longman.

18. Zainuddin, $S$ (2020). Some Aspects of Society and Religious Movement among Muslims "The Case of Tablighi Jamaat in Orissa." Publications Division, Aligarh Muslim University. 